\title{
PAIXÃO EMPREENDEDORA: UM ESTUDO BIBLIOMÉTRICO
}

Carla Cazella ${ }^{1}$

Hilka Pelizza Vier Machado ${ }^{1}$

${ }^{1}$ Universidade do Oeste de Santa Catarina (UNOESC) 


\section{PAIXÃO EMPREENDEDORA: UM ESTUDO BIBLIOMÉTRICO}

Resumo: Esta pesquisa tem como objetivo mapear os estudos sobre paixão empreendedora, a fim de compreender a evolução e potencialidades de estudo. Para isso foi realizado um estudo bibliométrico da produção científica sobre o tema paixão empreendedora, realizado nas bases de dados Scopus, Web of Science e Science Direct.Na análise bibliométrica, com auxílio do softwareStart, foram selecionados 665 artigos científicos, após os critérios de exclusão restaram 64 artigos. A análise bibliométrica possibilitou descrever a evolução de publicação no campo, os estudos mais citados, a contribuição dos periódicos, e os principais temas pesquisados. Conclui-se que a paixão empreendedora é um campo recente de estudos, com potencial para estudos futuros. O estudo contribui para compreensão do conhecimento acumulado sobre Paixão Empreendedora, estabelecendo assim algumas bases sobre as quais estudantes, mestrandos e doutorandos, professores e empreendedores possam construir suas agendas de pesquisa e aprofundar os conhecimentos sobre o tema.

Palavras-chave: Paixão Empreendedora. Bibliometria. Comportamento Empreendedor. Empreendedorismo.

\section{$1 \quad$ Introdução}

A importância das emoções para o campo do Empreendedorismo foi salientada por Baron (1998), que reconheceu o papel de sentimentos, afeto e emoções sobre as estruturas cognitivas e sobre a tomada de decisão. Entre os sentimentos, a paixão é um sentimento positivo que passou a ser discutido no campo do empreendedorismo, resultando no conceito de paixão empreendedora, compreendida como: "um estado afetivo intenso do empreendedor acompanhado por manifestações cognitivas e comportamentais de elevado valor pessoal" (Chen et al. 2009, p. 199).

Como um constructo, a paixão empreendedora passou a ser estudada no campo do Empreendedorismo, sugerindo-se inclusive a sua mensuração (Cardon, Gregoire, Stevens \& Patel,2013). Embora seja um tema recente, ele vem sendo explorado, tanto como variável dependente, como independente (Stroe, Parida \&Wincent, 2019).

Diante do exposto, esta pesquisa tem como objetivo identificar o estado da arte de publicações sobre paixão empreendedora, bem como, identificar a evolução e potencial de pesquisa no campo. Assim, surge como questionamento da pesquisa: Como se configura o estado atual da produção científica sobre paixão empreendedora?Para responder a esse questionamento, apresenta-se um estudo bibliométrico sobre paixão empreendedora, a partir de um levantamento da produção científica nas bases Scopus, Web of Science e Science Direct. A razão para a escolha destas bases de dados está associada ao número de periódicos indexados por estas, sendo que a Scopus apresenta maior abrangência mundial. Desta forma, espera-se contribuir com a literatura sobre paixão empreendedora, e possibilitar novos direcionamentos para a pesquisa, contribuindo para o avanço da consolidação da literatura. 
A estrutura do artigo inicia com uma breve revisão teórica do tema da pesquisa. Em seguida, apresenta os métodos utilizados e o quadro geral dos resultados. Por fim, aborda tendências, sugerindo pesquisas futuras.

\section{Breve Revisão do Campo de Pesquisa}

A paixão empreendedora é um constructo importante para a centralidade da identidade (Cardon et al. 2013). Ela pode ser definida como "sensações positivas intensas conscientemente experimentadas pelo engajamento em atividades empreendedoras associadas a papéis que são significativos e salientes para a identidade do empreendedor" (Cardon et al. 2009, p. 517).Vallerand et al. (2003) identificaram dois tipos: paixão obsessiva e paixão harmoniosa. A paixão harmoniosa deriva do prazer pela atividade e não por fatores ou pressões e possibilita a abertura para novas experiências. A paixão obsessiva resulta de pressões intrapessoais, como por exemplo uma necessidade de aceitação social e direciona o comportamento para focar em objetivos, mais do que na tarefa em si (Stroe, Parida \&Wincent, 2019).

Emoções positivas como a paixão empreendedora revelam-se importantes para guiar a tomada de decisão e o comportamento de empreendedores, sendo que a paixão pode contribuir para aumentar a persistência (Baron, 1998; Cardon et al. 2013). A paixão pode ainda influenciar o comportamento de investidores, clientes e empregados (Obschonka, Moeller\&Goethner, 2019). Além disso, ela é importante para a criatividade e para motivação do empreendedor e de sua equipe (Cardon et al. 2013).

De acordo com Cardon et al. (2013), a paixão empreendedora pode apresentar três dimensões: paixão pela invenção, paixão pela criação e paixão pelo desenvolvimento. $\mathrm{O}$ empreendedor pode desenvolver paixão para o desenvolvimento de produtos e serviços ou para identificação e criação de oportunidades. Nesse sentido, Warnick et al. (2019) distinguem dois tipos: a paixão pela criação do produto ou paixão pela criação da empresa. A paixão pela criação de empresas pode influenciar empreendedores habituais, aqueles que criam diversos negócios (Cardon et al. 2013). Já a paixão pelo desenvolvimento do empreendimento pode ser notada por meio do envolvimento do empreendedor no aumento das vendas, na contratação de empregados e no acesso a investidores (Cardon et al. 2013).

A partir dessas considerações, pode-se perceber que a paixão empreendedora é um constructo relevante para a criação e o desenvolvimento de pequenos negócios. No entanto, como é um tema de estudos recente acredita-se que existam ainda há muito explorar sobre o tema.

\section{Procedimentos Metodológicos}

O presente estudo bibliométrico visa compreender o estado da arte da pesquisa sobre Paixão Empreendedora. O estudoé concentrado em artigos publicados nos principais periódicos internacionais de língua inglesa, selecionadosnas bases de dados Scopus, Web of Science e ScienceDirect, com auxilio do software Start. Foram selecionados 665 artigos científicos, após os critérios de exclusão restaram 64 artigos. Estudos bibliométricos têm sua importância para a academia por identificar o estado da arte e caracterizar tendências de um determinado assunto, além de fornecerem indicadores científicos para auxiliar pesquisadores. 
O fluxo de trabalho da presente pesquisa (Figura 1) iniciou com a definição dos critérios de seleção dos periódicos, seguiu com a coleta e a triagem dos artigos, e por fim apresentam-se os resultados obtidos das análises. Para desenvolver a análise das palavras chaves, primeiramente foi utilizado o VOSviewer, criando um mapa dos dados coletados.

A coleta de dados foi baseada em técnica bibliométrica, sendo esta útil ao analisar grandes volumes de informação. Bibliometria é um método científico estabelecido e utilizado para controlar, medir e mapear comunicação científica através de domínios e disciplinas (Ramos-Rodriguez e Ruiz-Navarro 2004). O objetivo desta bibliometria foi examinar padrões na pesquisa existente (Ferreira, 2013).A Bibliometria deste estudo propiciou a identificação da amplitude e da natureza de publicações voltadas ao tema paixão empreendedora, auxiliando na compreensão do campo e possibilitando a definição da questão de pesquisa. A técnica de análise bibliométrica possibilitou observar a evolução quantitativa da literatura do tema, empregando medidas de indicadores de publicação, como número de artigos publicados por periódicos, número de citações dos autores, principais temas abordados nos estudos. Estudos bibliométricos apresentam valiosa importância para os pesquisadores, fornecendo indicadores da produção científica e padrões na pesquisa existente.

Para melhor entendimento do fluxo da pesquisa, é possível observar o fluxo na figura 1 . $\mathrm{O}$ fluxo do desenvolvimento da pesquisa iniciou com a formulação da questão de pesquisa, para compreender o estado da arte da pesquisa sobre paixão empreendedora. Após elaborou-se os descritores utilizados na busca dos assuntos relacionados ao tema, e definiram-se os critérios de seleção das bases e dos periódicos. O levantamento inicial dos artigos selecionados foi limitado à pesquisa pelas palavras chave, resumo e título dos artigos, e utilizados como termos de pesquisa: ("Entrepre*AND Passion").

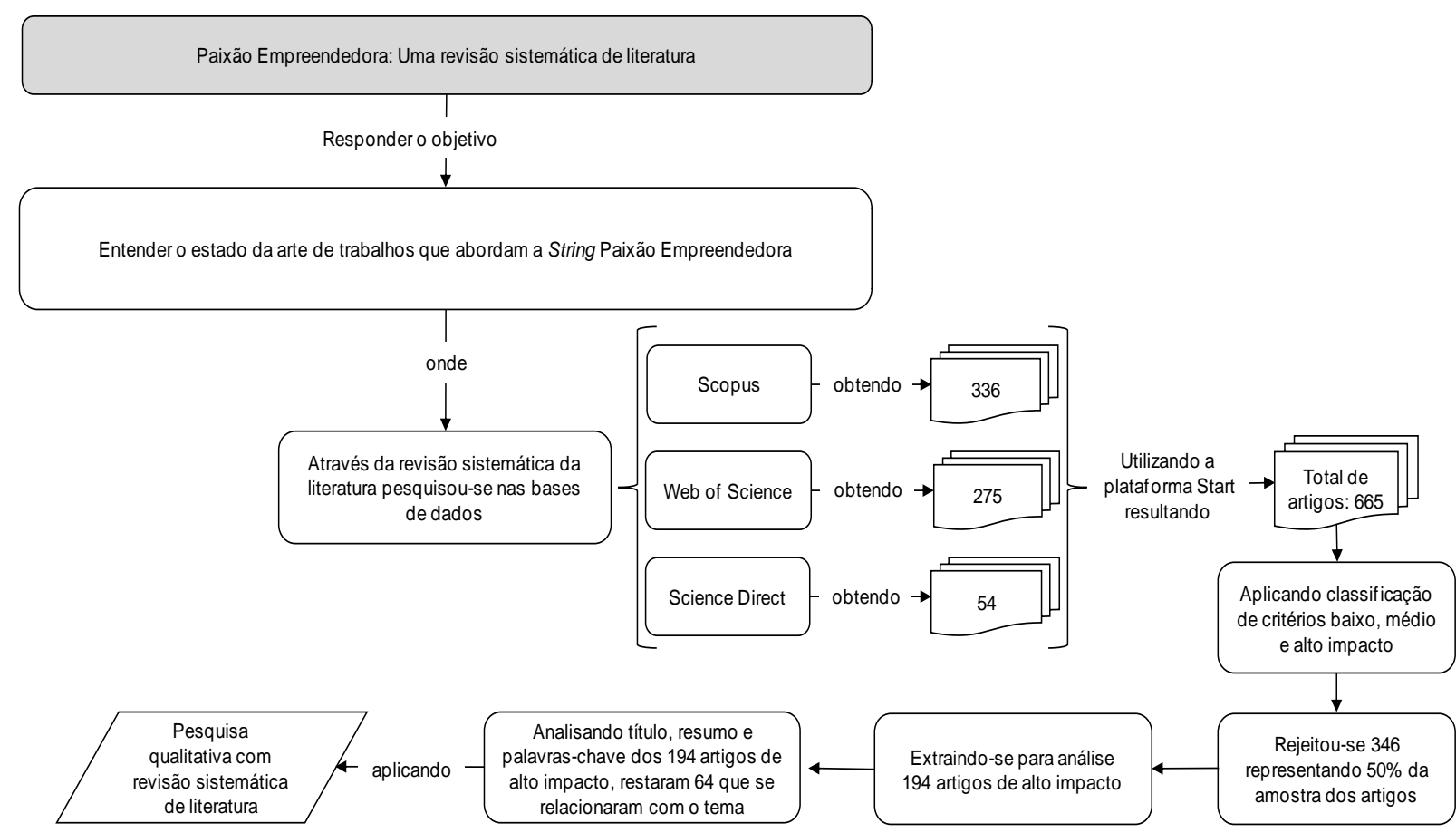


Figura 1 - Fluxo de desenvolvimento da pesquisa

A busca dos artigos foi realizada nas bases de dados eletrônicas Scopus, Web of Science e ScienceDirect, na primeira quinzena de junho de 2019, a primeira triagem da pesquisa resultou em 665 artigos. Aplicando o software Start com as classificações de alto, médio e baixo impacto, rejeitou-se 346 artigos. Dos restantes foram lidos os títulos e palavras chave, extraindo para leitura dos resumos 194 artigos. Destes, depois de realizada a leitura dos resumos, foram selecionados 64 para leitura na íntegra, que compõem a amostra final. Nesta leitura utilizaram-se como critério de inclusão para a classificação dos artigos, aqueles que tinham em suas palavras-chave, título e resumo, os termos de busca estabelecidos.

Em caráter de complementaridade, foram as 3 bases de dados nominadas anteriormente que produziram o melhor resultado em termos de cobertura de artigos publicados sobre a temática. $\mathrm{Na}$ pesquisa, foram realizados testes de buscas nas bases Ebsco, Wiley, Spring, Spell e Emerald, mas os artigos encontrados já estavam relacionados pelas bases anteriores, o que foi considerado critério de exclusão dessas bases para o mapeamento de artigos.

Para critério de baixa e seleção dos artigos foi utilizado o software Start, na figura 2 é possível observar a quantidade de artigos por Base pesquisada.

\section{Sources}

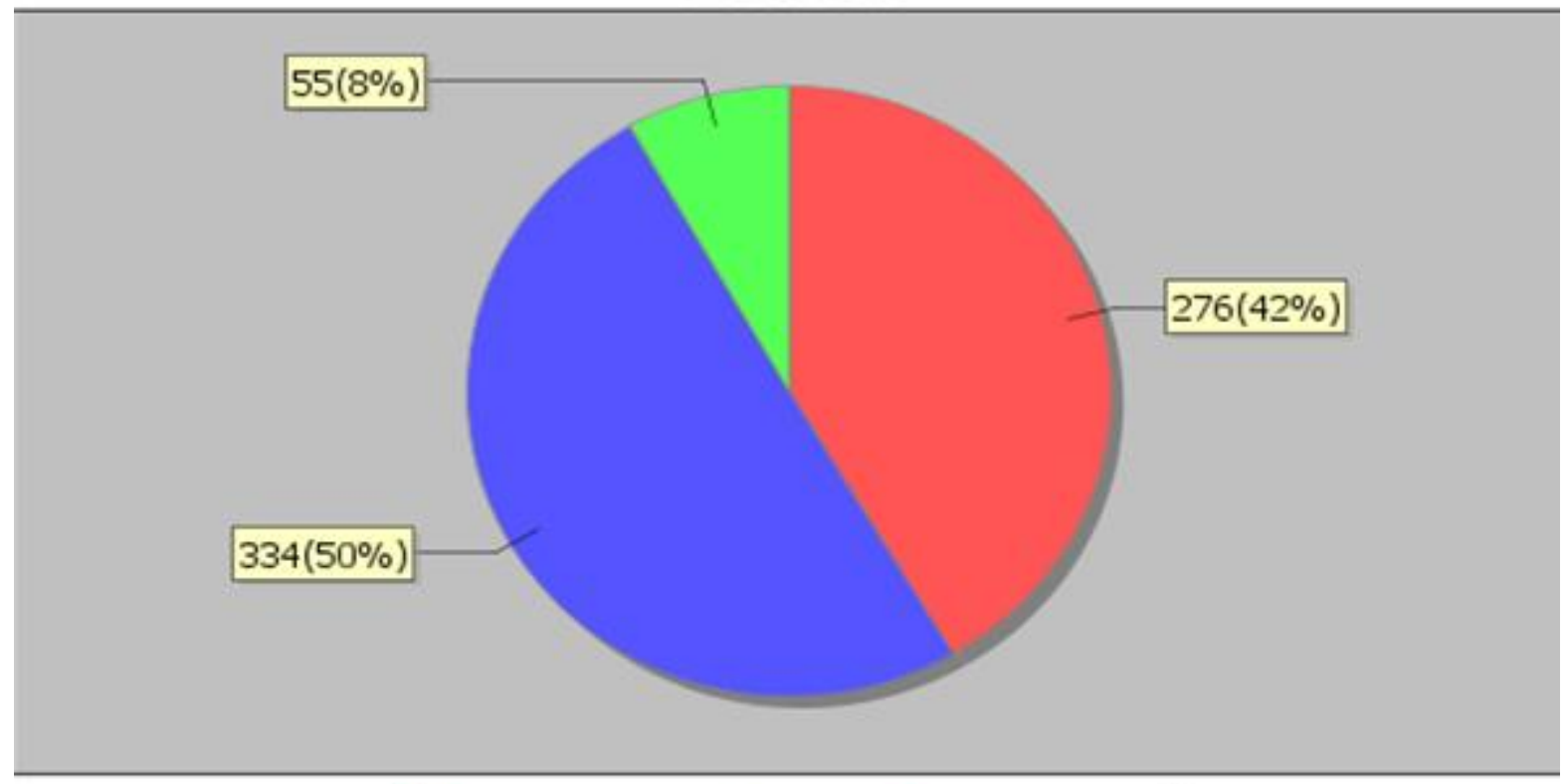

Web of Science - Scopus Science Direct

Figura 2: Bases de Dados pesquisadas e total de artigos publicados

No gráfico (figura 2) identifica-se 334 artigos da Base Scopus, 276 da base Web of Science e 55 artigos da base Science Direct, totalizando 665 artigos. Com base nesse levantamento, seguiu-se com a coleta e a classificação dos artigos, restaram na amostra final 64 artigos. Após a análise do conteúdo dos 64 artigos selecionados, categorizaram-se e sistematizaram-se os artigos, a fim de identificar a evolução quantitativa (ano de publicação, periódicos, citações por autor e abordagem metodológica,), bem como as principais temáticas abordadas nos estudos, e as possíveis tendências da pesquisa sobre paixão empreendedora. 
Ainda na análise dos 665 artigos, utilizando o software VOSviewer (Perssonet et al., 2009), antes de iniciar a triagem dos artigos, analisou-se as palavras-chave dos artigos selecionados (Figura 3). Nesta análise percebe-se a centralidade do termo Paixão Empreendedora, sendo a palavra-chave do maior cluster com conexão direta com Negócios, o que justifica a maioria dos estudos serem empíricos.

B vosviewer

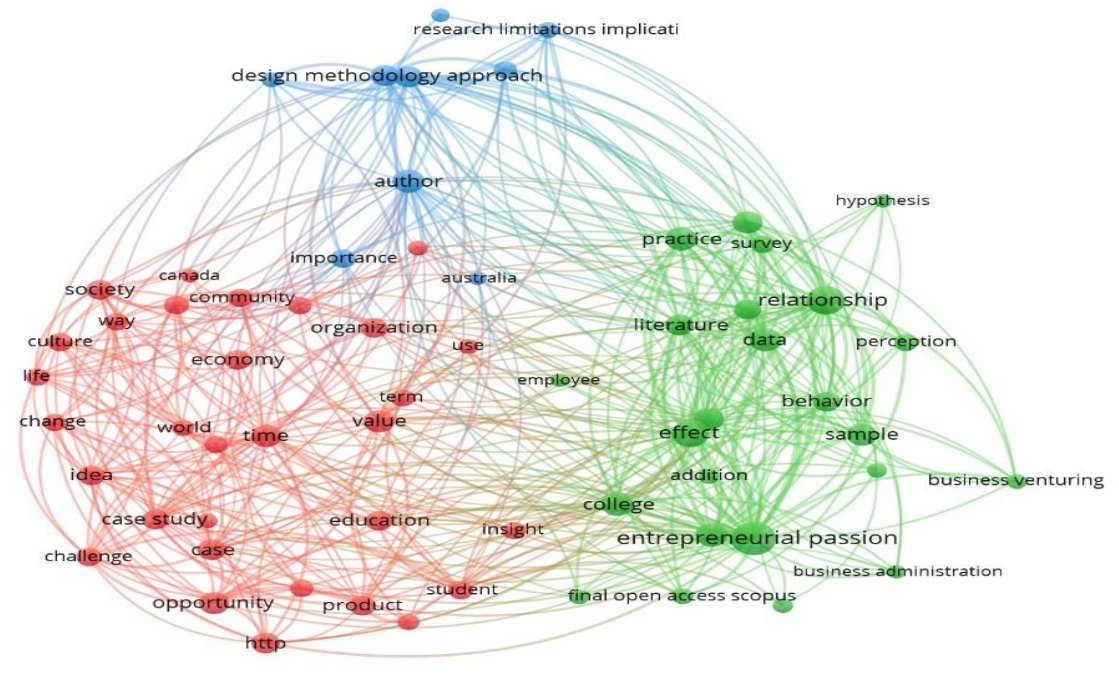

Figura 3: Palavras que mais aparecem como palavras chave

\section{Discussão dos Resultados: Quadro Geral da Pesquisa sobre Paixão Empreendedora}

A fim de descrever a evolução quantitativa e a estrutura da literatura sobre paixão empreendedora, e com base nos procedimentos metodológicos foram identificados 64 artigos científicos, publicados em periódicos conforme Tabela1. Do total de estudos selecionados nesta pesquisa, a concentração de maior número de publicações acontece a partir do ano de 2014, conforme representado na figura 4. Isso demonstra que a pesquisa sobre paixão empreendedora vem crescendo e revela que o tema é um paradigma de pesquisa crescente, masque não se esgotou. 


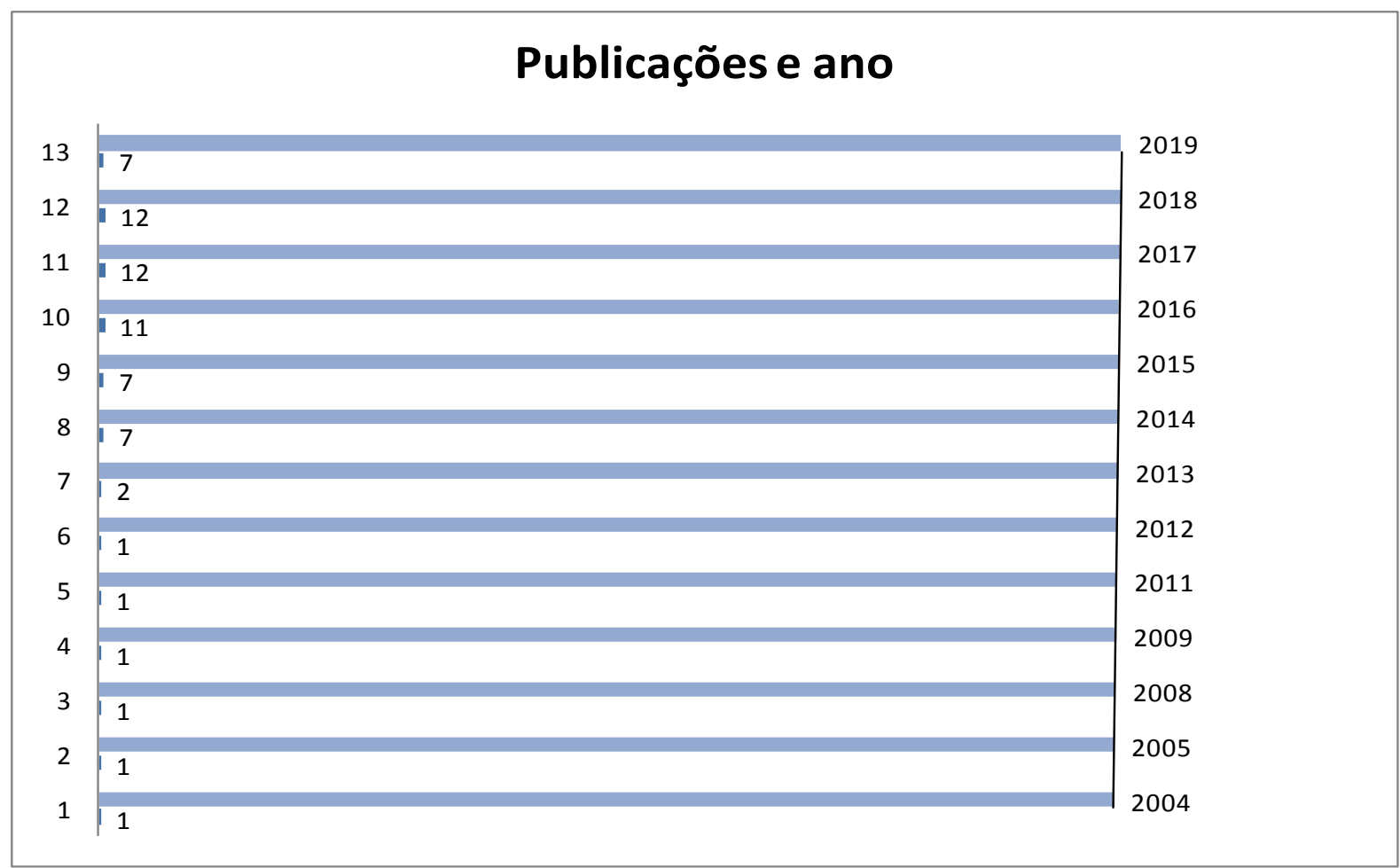

Figura 4 - Ano de publicação e número de artigos publicados

Nota-se na figura 4, que até o ano de 2013 foram publicados no máximo dois artigos por ano. Foi a partir de 2014 que o tema passou a despertar maior interesse, com sete artigos publicados no ano e a maior produção de artigos na temática passou a se intensificar em 2016, com 11 artigos publicados. O ano de 2019 representa a produção apenas até o mês de julho.

As análises de citações apresentam a frequência com que determinado estudo é referenciado por outros trabalhos (Ramos-Rodríguez\&Ruíz-Navarro, 2004), sendo reconhecidos pelo impacto sobre o campo de estudo (Ferreira, 2011).Em relação aos artigos com maior número de citações, identifica-se o artigo mais citado The relation shipof entrepreneurial traits, skill, and motivation to subsequent venture growth, com 2005 citações, seguido do artigo The nature and experience of entrepreneurial passion com 1171 citações. Em terceiro lugar, o Entrepreneur passion and preparedness in business plan presentations: A persuasion analysis of venture capitalists' fundingdecisions com 671 citações, e, em quarto, o artigo A tale of passion: New insights into entrepreneurship from a parenthood metaphor com 582 citações. Estes foram estudos publicados entre os anos 2005 e 2009, o que demonstra serem estudos pioneiros.

Tabela 1 - Artigos selecionados e citações

\begin{tabular}{llccc}
\hline Autor & \multicolumn{1}{c}{ Título } & Ano & $\begin{array}{c}\text { Citaç } \\
\text { oes }\end{array}$ \\
\hline Baum J.R., Locke E.A. & $\begin{array}{l}\text { The relationship of entrepreneurial traits, skill, and } \\
\text { motivation to subsequent venture growth. }\end{array}$ & 2004 & 2005 \\
$\begin{array}{l}\text { Cardon M.S., Zietsma C., } \\
\text { Saparito P., Matherne B.P., }\end{array}$ & $\begin{array}{l}\text { A tale of passion: New insights into entrepreneurship from } \\
\text { a parenthood metaphor }\end{array}$ & 2005 & 582 \\
\hline
\end{tabular}


Davis C.

Cardon M.S.

Is passion contagious? The transference of entrepreneurial 2008

Cardon M.S., Wincent J., The nature and experience of entrepreneurial passion

Singh J., Drnovsek M.

Chen X.-P., Yao X., Kotha S. Entrepreneur passion and preparedness in business plan

Laaksonen L., Ainamo A., Entrepreneurial passion: An explorative case study of four

Breugst N., Domurath A., Perceptions of Entrepreneurial Passion and Employees'

Patzelt H., Klaukien A.

Commitment to Entrepreneurial Ventures

De ClercqD., Honig B., The roles of learning orientation and passion for work in Martin B.

the formation of entrepreneurial intention

Cardon M.S., Gregoire D.A.

Measuring

foundations and scale validation

Shepherd D.A., Wiklund J.,

Michael Haynie J.

Jamil A., Omar R., Panatik

S.A.

Moving forward: Balancing the financial and emotional costs of business failure

Identity threat, resistance to chance and entrepreneurial behavioural engagements: The moderating role of entrepreneurial passion

Jamil A., Omar R., Panatik Entrepreneurial passion, achievement motivation goals and S.A.

behavioural engagements in Malaysia: Are there any differences across ethnic groups?

Ho V.T., Pollack J.M.

Passion isn't always a good thing: Examining entrepreneurs' network centrality and financial performance with a dualistic model of passion

Murnieks C.Y., Mosakowski

Pathways of Passion: Identity Centrality, Passion, and Behavior Among Entrepreneurs

E., Cardon M.S.

Hybrid entrepreneurship: The importance of passion

2012

2013

Thorgren S., Nordström C.

Wincent J.

Envick B.R.

Achieving entrepreneurial success through passion, vision \& courage: A cognitive model for developing entrepreneurial intelligence

Dalborg C., Wincent J.

The idea is not enough: The role of self-efficacy in mediating the relationship between pull entrepreneurship and founder passion - a research note

Fink M., Hatak I., Lang R., Entrepreneurship research without passion: Let's fall in Maresch D.

Thorgren S., Wincent J.

love again

Passion and habitual entrepreneurship

2014

7

Nasiru A., Keat O.Y., Bhatti M.A.

Dalborg C., von Friedrichs Y., Wincent J.

Gielnik M.M., Spitzmuller Influence of perceived university support, perceived effective entrepreneurship education, perceived creativity disposition, entrepreneurial passion for inventing and founding on entrepreneurial intention

Risk perception matters: Why women's passion may not lead to a business Start-Up

"I put in effort, therefore I am passionate": Investigating 2015

M., Schmitt A., Klemann the path from effort to passion in entrepreneurship

D.K., Frese M

Cardon M.S., Kirk C.P.

Entrepreneurial Passion as Mediator of the Self-Efficacy to 2015

Lucas K., Kerrick S.A., Communicating entrepreneurial passion: Personal Passion 2016 Haugen J., Crider C.J. vs. Perceived Passion in venture pitches 
Mooradian T., Matzler Perspiration and inspiration: Grit and innovativeness as 2016

K.,Uzelac B., Bauer F. antecedents of entrepreneurial success

Collewaert V., Anseel F., When Passion Fades: Disentangling the Temporal 2016 Crommelinck M., De Dynamics of Entrepreneurial Passion for Founding

Beuckelaer A., Vermeire J.

Stenholm P., Renko M.

Passionate bricoleurs and new venture survival

2016

Adomako S., Quartey S.H., Narteh B.

Murnieks C.Y., Cardon M.S., Sudek R., White T.D., Brooks W.T.

Drnovsek M., Cardon M.S. Patel P.C.

Nordström C., Sirén C.A., Thorgren S., Wincent J.

Yitshaki R., Kropp F.

Gerschewski S., Lindsay V.J., Rose E

Moses C.L., Olokundun

M.A., Akinbode M., Agboola M., Inelo F

Cardon M.S., Glauser M. Murnieks C.Y.

Ma C., Gu J., Liu H., Zhang Q.

Fellnhofer K.

Bagheri A., Yazdanpanah J.

Gielnik M.M., Uy M.A., Funken R., Bischoff K.M.

Mueller B.A., Wolfe M.T., Syed I.

Cardon M.S., Post C., Forster W.R

Ashkanasy N.M., Humphrey

R.H., Huy Q.N

Bao J.,Zhou X., Chen Y.

Montiel Campos H.

Biraglia A., Kadile V.

Pérez Zapata O., Álvarez Engagement and/or work intensification, choice and/or Hernández G., obligation?: "If you don't do what you love, you have to CastañoCollado C Milanesi M. environmental dynamism and firm performance in an emerging economy

Drawn to the fire: The role of passion, tenacity and 2016 inspirational leadership in angel investing

Direct and Indirect Effects of Passion on Growing 2016 Technology Ventures

Passion in hybrid entrepreneurship: the impact of 2016 entrepreneurial teams and tenure

Entrepreneurial passions and identities in different 2016 contexts: a comparison between high-tech and social entrepreneurs

Advancing the entrepreneurial orientation construct: the role of passion and perseverance

Entrepreneurship education and entrepreneurial intentions: 2016

The moderating role of passion

Passion for what? Expanding the domains of 2017 entrepreneurial passion

Entrepreneurial passion and organizational innovation: the moderating role of the regulatory focus of entrepreneurs

The power of passion in entrepreneurship education: 2017

Entrepreneurial role models encourage passion?

Novice entrepreneurs' entrepreneurial self-efficacy and passion for entrepreneurship

Boosting and sustaining passion: A long-term perspective on the effects of entrepreneurship training

Passion and grit: An exploration of the pathways leading to venture success

Team entrepreneurial passion: Its emergence and influence in new venture teams

Integrating emotions and affect in theories of management

Entrepreneurial passion and behaviors: Opportunity recognition as a mediator

Impact of entrepreneurial passion on entrepreneurial orientation with the mediating role of entrepreneurial alertness for technology-based firms in Mexico

The Role of Entrepreneurial Passion and Creativity in Developing Entrepreneurial Intentions: Insights from American Homebrewers

G., obligation?: "If you
love what you do"

Exploring passion in hobby-related entrepreneurship. $2018 \quad 4$ Evidence from Italian cases.
26

34

44

06

65

0

6

1

35

48

63

2

5

67

1 
Ranfagni S., Runfola A.

Arshad M., Farooq O., Afzal S.

Stroe S., Wincent J., Parida V.

Stroe S., Parida V., Wincent J.

Warnick B.J., Murnieks C.Y., McMullen J.S., Brooks W.T. Bhansing P.V., Hitters E., Wijngaarden Y.

Fisher R., Merlot E., Johnson L.W.

Liang X., Jiang J., Li E.Y.

Oo P.P., Allison T.H., Sahaym A., Juasrikul S.

Pertiwi N., Taufieq N.A.S., Mithen

Suvittawat A.

Obschonka M., Moeller J., Goethner M.

Ko W.W., Liu G., Wan Yusoff W.T., Che Mat C.R.

St-Jean É., Fonrouge C.

Santos, Susana C., Cardon,

Melissa S.

Hou, Fei and $\mathrm{Su}, \mathrm{Yu}$ and $\mathrm{Lu}$, Minru and Qi, Mingde

Liu, Feng and Ma, Jiangshui and Li, Ran
Connecting passion: Distinctive features from emerging 2018 entrepreneurial profiles

The role of entrepreneurship education in developing a 2018 passion for business

Untangling intense engagement in entrepreneurship: Role overload and obsessive passion in early-stage entrepreneurs

Effectuation or causation: An fsQCA analysis of 2018 entrepreneurial passion, risk perception, and self-efficacy

Passion for entrepreneurship or passion for the product? A 2018 conjoint analysis of angel and VC decision-making

Passion Inspires: Motivations of Creative 2018

Entrepreneurs in Creative Business Centers in the Netherlands

The obsessive and harmonious nature of entrepreneurial passion

IT-based entrepreneurship in sharing economy: The mediating role of value expectancy in micro-entrepreneur's passion and persistence

User entrepreneurs' multiple identities and crowdfunding performance: Effects through product innovativeness, perceived passion, and need similarity

Relation the entrepreneurship passion of farmer and the riverbank management

Passions and enthusiasm of small and medium enterprises (SMES): A case study of Nakorn Ratchasima province, Thailand

2018 5

2018

2018

Entrepreneurial passion and personality: The case of 2019 academic entrepreneurship

Social Entrepreneurial Passion and Social Innovation 2019

Performance

Comment developer l'auto-efficacitéentrepreneuriale? 2019 Étudeauprèsd'étudiantsuniversitaires

What's Love Got to Do With It? Team Entrepreneurial 2019

Passion andPerformance in New Venture Teams

Model of the Entrepreneurial Intention of University 2019

Students in thePearl River Delta of China

Which Role Model Is More Effective in Entrepreneurship 2019 ention

A autora que mais publicou foi Cardon, presente em nove dos 64 artigos como autora ou coautora. Outros autores que publicaram dois artigos cada um foram Stroe e Jamil. É importante salientar que o artigo de Baum foi o mais citado, mas ele não discute diretamente o constructo da paixão empreendedora. Nesse sentido, o trabalho seminal é o Cardon M.S., Wincent J., Singh J., DrnovsekM.(2009). The natureandexperienceofentrepreneurialpassion, citado 1171 vezes.

Os periódicos que mais publicaram artigos foram: Journalof Business Venturing com 10 publicações e fator de impacto 6, Journalof Business Research com 5 publicações dos 64 
artigos analisados e fato de impacto 3.354 e o Entrepreneurshipand Regional Development com 4 publicações e fator de impacto 2.791, como se observa na Tabela 2.

$\underline{\text { Tabela 2. Periódicos, publicações e fator de impacto dos artigos }}$

\begin{tabular}{|c|c|c|}
\hline Jounal & $\begin{array}{r}\mathrm{N} \\
\text { Publicações } \\
\end{array}$ & $\begin{array}{r}\text { Fator } \\
\text { de impacto }\end{array}$ \\
\hline Journalof Business Venturing & 10 & 6.0 \\
\hline Journalof Business Research & 5 & 3.354 \\
\hline Entrepreneurshipand Regional Development & 4 & 2.791 \\
\hline AcademyofEntrepreneurshipJournal & 3 & 0.22 \\
\hline Academyof Management Review & 3 & 6.7 \\
\hline Frontiers in Psychology & 3 & 2.089 \\
\hline Asian Social Science & 2 & 0.278 \\
\hline BalticJournalof Management & 2 & 1.103 \\
\hline International Small Business Journal: Researching Entrepreneurship & 2 & 3.248 \\
\hline JournalofEntrepreneurshipEducation & 2 & 0.43 \\
\hline Journalof Management Studies & 2 & 5.329 \\
\hline Journal of Small Business and Enterprise Development & 2 & 1.49 \\
\hline Global Business and Organizational Excellence & 1 & 0.23 \\
\hline HumanResource Management Review & 1 & 3.272 \\
\hline IEEE Transactions on Professional Communication & 1 & 0.756 \\
\hline International Journal of Entrepreneurial Behaviour and Research & 1 & 1.863 \\
\hline International Journal of Gender and Entrepreneurship & 1 & 1.00 \\
\hline International Journal of Information Systems and Change Management & 1 & - \\
\hline InternationalSmall Business Journal & 1 & 3.248 \\
\hline Iranian Entrepreneurship & 1 & - \\
\hline JournalofAppliedPsychology & 1 & 7.121 \\
\hline JournalofDevelopmentalEntrepreneurship & 1 & 0.46 \\
\hline JournalofEconomicPsychology & 1 & 1.561 \\
\hline JournalofEntrepreneurship & 1 & 1.561 \\
\hline Journalof Management & 1 & 8.08 \\
\hline Journal of Research in Marketing and Entrepreneurship & 1 & 0.22 \\
\hline Journal of Small Business and Entrepreneurship & 1 & 1.49 \\
\hline Journal of Small Business Management & 1 & 1.937 \\
\hline Mediterranean Journal of Social Sciences & 1 & 3.77 \\
\hline Nonprofit and Voluntary Sector Quarterly & 1 & 1.932 \\
\hline Politica y Sociedad & 1 & 0.18 \\
\hline Rethinking Entrepreneurship: Debating Research Orientations & 1 & - \\
\hline Review of International Business and Strategy & 1 & 0.3 \\
\hline Social BehaviorandPersonality & 1 & 0.548 \\
\hline Social Sciences (Pakistan) & 1 & 0.13 \\
\hline
\end{tabular}


Quanto aos métodos utilizados nas publicações, conforme dados apresentados naTabela3, a abordagem quantitativa foi predominante, utilizada na metade dos artigos publicados. Em seguida, estudos qualitativos com dados em doze artigos foram os principais métodos utilizados.

Tabela3. Parâmetros Metodológicos das pesquisas

\begin{tabular}{lll}
\hline Método & Técnicas de análise predominantes & N de Artigos \\
\hline Revisão da literatura & Análise de conteúdo & 2 \\
Ensaio teórico & Sugestão de proposições & 8 \\
Estudos quantitativos & Análise de Equações Estruturais, Análise & 32 \\
& Econométrica, Análise Fatorial, Analise de & \\
& Regressão & 12 \\
Estudos qualitativos & Triangulação e análise de conteúdo & 10 \\
Estudos mistos & Análise fatorial e fsQCA & \\
\hline
\end{tabular}

Analisando as palavras chaves, como mostra a nuvem de palavras na figura 5, nota-se que os temas liderança, auto eficácia, identidade e criatividade aparecem como variáveis utilizadas nos estudos. Além destas, a categorização paixão obsessiva e paixão harmoniosa aparece na nuvem de palavras.

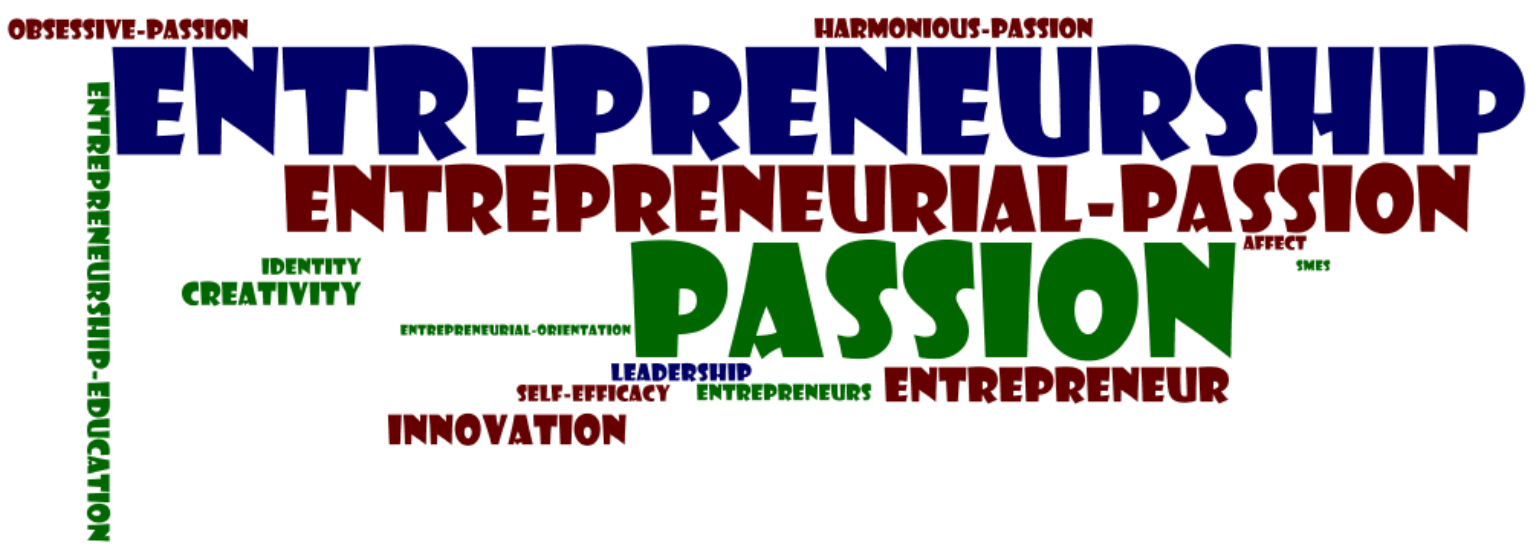

Figura 5: Palavras que mais aparecem como palavras chave: (utilizado o Word cloud do software Start)

Em síntese, os resultados deste estudo mostraram que a temática Paixão Empreendedora foi um tema introduzido inicialmente no período 2005-2009, mas que passou a demonstrar interesse maior dos pesquisadores a partir de 2014. A autora que mais influenciou as publicações no campo foi Cardon. Ela é uma das co-autoras da publicação diretamente associada ao tema e mais citada, que foi publicada em 2009. A maioria dos estudos publicados foram estudos quantitativos.

\section{Considerações Finais}


Este estudo teve como objetivo demonstrar como se configura o estado da arte da pesquisa sobre paixão empreendedora. A análise bibliométrica possibilitou descrever a evolução de publicação no campo.Até o ano de 2013 foram publicados no máximo dois artigos por ano e foi a partir de 2014 que o tema passou a despertar maior interesse, com sete artigos publicados no ano e a maior produção na temática passou a se intensificar em 2016, com 11 artigos publicados. O ano de 2019 representa a produção apenas até o mês de julho.A autora que mais publicou foi Melissa Cardon, com nove artigos. Entre os temas identificados nas palavras chave constam criatividade, identidade, os estudos mais citados, a contribuição dos periódicos, e os principais temas pesquisados. Conclui-se que a paixão empreendedora é um campo recente de estudos, com potencial para estudos futuros. O estudo contribui para compreensão do conhecimento acumulado sobre Paixão Empreendedora, estabelecendo algumas bases sobre as quais estudantes, mestrandos e doutorandos, professores e empreendedores possam construir agendas de pesquisa sobre o tema.Como limitação, destacase a necessidade de ampliar as análises sobre o conteúdo das publicações, sugestão para estudos futuros.

\section{Referências}

Adomako, S., Howard Quartey, S., \&Narteh, B. (2016). Entrepreneurial orientation, passion for work, perceived environmental dynamism and firm performance in an emerging economy. Journal of Small Business and Enterprise Development, 23(3), 728752. doi:10.1108/jsbed-08-2015-0115

Arshad M., Farooq O., Afzal S.2018) The role of entrepreneurship education in developing a passion for business. Global Business and Organizational Excellence, 37, doi 10.1002/joe.21896.

Ashkanasy, N. M., Humphrey, R. H., \&Huy, Q. N. (2017). Integrating Emotions and Affect in Theories of Management. Academy of Management Review, 42(2), 175-189. doi:10.5465/amr.2016.0474

Bagheri, A., \&Yazdanpanah, J. (2017). Novice Entrepreneurs' Entrepreneurial Selfefficacy and Passion for Entrepreneurship. Iranian Entrepreneurship, 7389. doi:10.1007/978-3-319-50639-5_5

Bao, J., Zhou, X., \& Chen, Y. (2017). Entrepreneurial Passion and Behaviors: Opportunity Recognition As a Mediator. Social Behavior and Personality. An International Journal, 45(7), 1211-1220. doi:10.2224/sbp.6492

Baron, R. A. (1998). Cognitive Mechanisms in Entrepreneurship: Why and When Entrepreneurs think differently than other people. Journal of business Venturing, 13, 275-294.

Baum, J. R., \& Locke, E. A. (2004). The Relationship of Entrepreneurial Traits, Skill, and Motivation to Subsequent Venture Growth. Journal of Applied Psychology, 89(4), 587598. doi:10.1037/0021-9010.89.4.587

Bhansing, P. V., Hitters, E., \&Wijngaarden, Y. (2018). Passion Inspires: Motivations of Creative Entrepreneurs in Creative Business Centers in the Netherlands. The Journal of Entrepreneurship, 27(1), 1-24. doi:10.1177/0971355717738589 
Biraglia, A., \&Kadile, V. (2016). The Role of Entrepreneurial Passion and Creativity in Developing Entrepreneurial Intentions: Insights from American Homebrewers. Journal of Small Business Management, 55(1), 170-188. doi:10.1111/jsbm.12242

Breugst, N., Domurath, A., Patzelt, H., \&Klaukien, A. (2011). Perceptions of Entrepreneurial Passion and Employees' Commitment to Entrepreneurial Ventures. Entrepreneurship Theory and Practice, 36(1), 171-192. doi:10.1111/j.15406520.2011.00491.x

Cardon, M. S. (2008). Is passion contagious? The transference of entrepreneurial passion to employees. Human Resource Management Review, 18(2), 7786. doi:10.1016/j.hrmr.2008.04.001

Cardon, M. S., Glauser, M., \&Murnieks, C. Y. (2017). Passion for what? Expanding the domains of entrepreneurial passion. Journal of Business Venturing Insights, 8, 24 32. doi:10.1016/j.jbvi.2017.05.004

Cardon, M. S., Gregoire, D. A., Stevens, C. E., \& Patel, P. C. (2013). Measuring entrepreneurial passion: Conceptual foundations and scale validation. Journal of Business Venturing, 28(3), 373-396. doi:10.1016/j.jbusvent.2012.03.003

Cardon, M. S., Post, C., \& Forster, W. R. (2017). Team Entrepreneurial Passion: Its Emergence and Influence in New Venture Teams. Academy of Management Review, 42(2), 283-305. doi:10.5465/amr.2014.0356

Cardon, M. S., Wincent, J., Singh, J., \&Drnovsek, M. (2009). The Nature And Experience Of Entrepreneurial Passion. Academy of Management Review, 34(3), 511532. doi:10.5465/amr.2009.40633190

Cardon, M. S., Zietsma, C., Saparito, P., Matherne, B. P., \& Davis, C. (2005). A tale of passion: New insights into entrepreneurship from a parenthood metaphor. Journal of Business Venturing, 20(1), 23-45. doi:10.1016/j.jbusvent.2004.01.002

Chen, X.-P., Yao, X., \&Kotha, S. (2009). Entrepreneur Passion and Preparedness In Business Plan Presentations: A Persuasion Analysis Of Venture Capitalists' Funding Decisions. Academy of Management Journal, 52(1), 199214. doi:10.5465/amj.2009.36462018

Collewaert, V., Anseel, F., Crommelinck, M., De Beuckelaer, A., \&Vermeire, J. (2016). When Passion Fades: Disentangling the Temporal Dynamics of Entrepreneurial Passion for Founding. Journal of Management Studies, 53(6), 966995. doi:10.1111/joms.12193

De Clercq, D., Honig, B., \& Martin, B. (2013). The roles of learning orientation and passion for work in the formation of entrepreneurial intention. International Small Business Journal, 31(6), 652-676. doi:10.1177/0266242611432360

Drnovsek, M., Cardon, M. S., \& Patel, P. C. (2016). Direct and Indirect Effects of Passion on Growing Technology Ventures. Strategic Entrepreneurship Journal, 10(2), 194213. doi:10.1002/sej.1213

Envick B.R. (2014) Achieving entrepreneurial success through passion, vision \& courage: A cognitive model for developing entrepreneurial intelligence.Academy of Entrepreneurship Journal, 20(1):55-74 
FellnhoferK.(2017) . The power of passion in entrepreneurship education: Entrepreneurial role models encourage passion?Journal of Entrepreneurship Education, 20(1):58-87

Ferreira, M.; Frias, C.; \&Serra, F. (2013). The transaction costs theory in international business research: a bibliometric study over three decades.Scientometrics,98(3), 1899-1922. doi:10.1007/s11192-013-1172-8

Fisher, R., Merlot, E., \& Johnson, L. W. (2018). The obsessive and harmonious nature of entrepreneurial passion. International Journal of Entrepreneurial Behavior \& Research, 24(1), 22-40. doi:10.1108/ijebr-01-2017-0011.

Gerschewski, S., Lindsay, V. J., \& Rose, E. (2016). Advancing the entrepreneurial orientation construct: the role of passion and perseverance. Review of International Business and Strategy, 26(4), 446-471. doi:10.1108/ribs-08-2016-0042

Gielnik, M. M., Uy, M. A., Funken, R., \& Bischoff, K. M. (2017). Boosting and sustaining passion: A long-term perspective on the effects of entrepreneurship training. Journal of Business Venturing, 32(3), 334-353. doi:10.1016/j.jbusvent.2017.02.003

Ho, V. T., \& Pollack, J. M. (2013). Passion Isn't Always a Good Thing: Examining Entrepreneurs' Network Centrality and Financial Performance with a Dualistic Model of Passion. Journal of Management Studies, 51(3),

Hou, F., Su, Y., Lu, M., \&Qi, M. (2019). Model of the Entrepreneurial Intention of University Students in the Pearl River Delta of China. Frontiers in Psychology, 10. doi:10.3389/fpsyg.2019.00916

Jamil, A., Omar, R., \&Panatik, S. A. (2014). Entrepreneurial Passion, Achievement Motivation Goals and Behavioural Engagements in Malaysia: Are There Any Differences Across Ethnic Groups? Asian Social Science, 10(17). doi:10.5539/ass.v10n17p17

Jamil, A., Omar, R., \&Panatik, S. A. (2014). Identity Threat, Resistance to Chance and Entrepreneurial Behavioural Engagements: The Moderating Role of Entrepreneurial Passion. Asian Social Science, 10(17). doi:10.5539/ass.v10n17p1

Ko, W. W., Liu, G., Wan Yusoff, W. T., \& Che Mat, C. R. (2019). Social Entrepreneurial Passion and Social Innovation Performance. Nonprofit and Voluntary Sector Quarterly, 1-25. doi:10.1177/0899764019830243

Laaksonen, L., Ainamo, A., \&Karjalainen, T. (2011). Entrepreneurial passion: an explorative case study of four metal music ventures. Journal of Research in Marketing and Entrepreneurship, 13(1), 18-36. doi:10.1108/14715201111147923

Liang, X., Jiang, J. and Li, E.Y. (2018) 'IT-based entrepreneurship in sharing economy: the mediating role of value expectancy in micro-entrepreneur's passion and persistence', Int. J. Information Systems and Change Management, 10 (4), 352-373.

Liu F, Ma J and Li R(2019) Which role model is more effective? Storytelling and entrepreneurial intention in entrepreneurship education. Front. Psychol. 10:837. doi:10.3389/fpsyg.2019.00837

Lucas, K., Kerrick, S. A., Haugen, J., \& Crider, C. J. (2016). Communicating Entrepreneurial Passion: Personal Passion vs. Perceived Passion in Venture Pitches. IEEE Transactions on Professional Communication, 59(4), 363378. doi:10.1109/tpc.2016.2607818 
Ma, C., Gu, J., Liu, H., \& Zhang, Q. (2017). Entrepreneurial Passion And Organizational Innovation: The Moderating Role Of The Regulatory Focus Of Entrepreneurs. Journal of Developmental Entrepreneurship,

22(03), 1750020. doi:10.1142/s1084946717500200

Milanesi, M. (2018). Exploring passion in hobby-related entrepreneurship. Evidence from Italian cases. Journal of Business Research, 92, 423430. doi:10.1016/j.jbusres.2018.04.020

Montiel Campos, H. (2017). Impact of entrepreneurial passion on entrepreneurial orientation with the mediating role of entrepreneurial alertness for technology-based firms in Mexico. Journal of Small Business and Enterprise Development, 24(2), 353-374.

Mooradian, T., Matzler, K., Uzelac, B., \& Bauer, F. (2016). Perspiration and inspiration: Grit and innovativeness as antecedents of entrepreneurial success. Journal of Economic Psychology, 56, 232-243. doi:10.1016/j.joep.2016.08.001

Moses, C.L., Olokundun, M.A., Akinbode, M., Agboola, M. \& Inelo, F. (2016). Entrepreneurship education and entrepreneurial intentions: The moderating role of passion. The Social Sciences, 11, 645-653.

Mueller, B. A., Wolfe, M. T., \& Syed, I. (2017). Passion and grit: An exploration of the pathways leading to venture success. Journal of Business Venturing, 32(3), 260 279. doi:10.1016/j.jbusvent.2017.02.001

Murnieks, C. Y., Cardon, M. S., Sudek, R., White, T. D., \& Brooks, W. T. (2016). Drawn to the fire: The role of passion, tenacity and inspirational leadership in angel investing. Journal of Business Venturing, 31(4), 468484. doi:10.1016/j.jbusvent.2016.05.002

Murnieks, C. Y., Mosakowski, E., \& Cardon, M. S. (2012). Pathways of Passion. Journal of Management, 40(6), 1583-1606. doi:10.1177/0149206311433855

Nordström, C., Sirén, C. A., Thorgren, S., \&Wincent, J. (2016). Passion in hybrid entrepreneurship: the impact of entrepreneurial teams and tenure. Baltic Journal of Management, 11(2), 167-186. doi:10.1108/bjm-01-2015-0007.

Obschonka, M., Moeller, J., \&Goethner, M. (2019). Entrepreneurial Passion and Personality: The Case of Academic Entrepreneurship. Frontiers in Psychology, 9. doi:10.3389/fpsyg.2018.02697

Oo, P. P., Allison, T. H., Sahaym, A., \&Juasrikul, S. (2018). User entrepreneurs' multiple identities and crowdfunding performance: Effects through product innovativeness, perceived passion, and need similarity. Journal of Business Venturing. doi:10.1016/j.jbusvent.2018.08.005

Pérez Zapata, O., Álvarez Hernández, G., \&Castaño, C. (2017). Engagement y/o intensificacióndeltrabajo ¿opción y/o obligación?:Si no haceslo que te gusta, te tiene que gustarlo que haces. Política y Sociedad, 54(3). doi:10.5209/poso.52176

Pertiwi N., Taufieq N.A.S., Mithen. (2018).Relation the entrepreneurship passion of farmer and the riverbank management.J. Entrep. Educ., vol. 21, no. 4, pp. 1-8, 2018

Ramos-Rodriguez, A. R.; Ruiz-Navarro, J.(2004).Changes in the intellectual structure of strategic management research: a bibliometric study of the Strategic Management Journal, 1980-2000. Strategic Management Journal, v. 25, n. 10, p. 981-1004, 
Ranfagni, S., \&Runfola, A. (2018). Connecting passion: Distinctive features from emerging entrepreneurial profiles. Journal of Business Research. doi:10.1016/j.jbusres.2018.04.018

Santos, S. C., \&Cardon, M. S. (2018). What's Love Got to Do With it? Team Entrepreneurial Passion and Performance in New Venture Teams. Entrepreneurship Theory and Practice, 104225871881218. doi:10.1177/1042258718812185

Shepherd, D. A., Wiklund, J., \& Haynie, J. M. (2009). Moving forward: Balancing the financial and emotional costs of business failure. Journal of Business Venturing, 24(2), 134 148. doi:10.1016/j.jbusvent.2007.10.002

Stenholm, P., \&Renko, M. (2016). Passionate bricoleurs and new venture survival. Journal of Business Venturing, 31(5), 595-611. doi:10.1016/j.jbusvent.2016.05.004

St-Jean É., Fonrouge C. (2019). Comment developer l'auto-efficacitéentrepreneuriale? Étude auprèsd'étudiantsuniversitaires. Journal of Small Business \& Entrepreneurship, 31, 1 a 23. doi:10.1080/08276331.2018.1560842

Stroe, S., Parida, V., \&Wincent, J. (2018). Effectuation or causation: An fsQCA analysis of entrepreneurial passion, risk perception, and self-efficacy. Journal of Business Research, 89, 265-272. doi:10.1016/j.jbusres.2018.01.035

Stroe, S., Wincent, J., \&Parida, V. (2018). Untangling intense engagement in entrepreneurship: Role overload and obsessive passion in early-stage entrepreneurs. Journal of Business Research, 90, 59-66. doi:10.1016/j.jbusres.2018.04.040

Suvittawat A. (2019). Passions and enthusiams of small and medium enterprises (SMES): A case study of Nakorn Ratchasima province, Thailand. - Entrepreneurship and Sustainability Issues, 6, 1369-1379. doi: 10.9770/jesi.2019.6.3(22).

Thorgren, S., Nordström, C., \&Wincent, J. (2014). Hybrid entrepreneurship: the importance of passion. Baltic Journal of Management, 9(3), 314-329. doi:10.1108/bjm-112013-0175

Vallerand, R. J., Mageau, G. Léonard, C.R.M., Blanchard, C., Koestner, R., Gagné, M. (2003). Les passions de l'ame: On obsessive and harmonious passion. Journal of Personality and Social Psychology, 85(4), 756-767.

Warnick, B. J., Murnieks, C. Y., McMullen, J. S., \& Brooks, W. T. (2018). Passion for entrepreneurship or passion for the product? A conjoint analysis of angel and VC decisionmaking. Journal of Business Venturing, 33(3), 315-332. doi:10.1016/j.jbusvent.2018.01.002

Yitshaki, R., \& Kropp, F. (2016). Entrepreneurial passions and identities in different contexts: a comparison between high-tech and social entrepreneurs. Entrepreneurship \& Regional Development, 28(3-4), 206-233. doi:10.1080/08985626.2016.1155743 